\title{
Peningkatan Keterampilan Industri Rumah Tangga Bagi Ibu-Ibu Rumah Tangga Di Desa Cibadak, Kecamatan Ciampea, Kabupaten Bogor Melalui Pelatihan Dan Pendampingan Pembuatan Virgin Coconut Oil (VCO)
}

\author{
Prasetyorini, Moerfiah, Iyan Mulyana \\ Universitas Pakuan Bogor
}

\begin{abstract}
Abstrak: Desa Cibadak adalah Desa yang terletak di Kecamatan Ciampea, Kabupaten Bogor. Salah satu kendala di bidang ekonomi di Desa Cibadak adalah pada aspek industri, terutama industri rumah tangga. Berdasarkan masalah ini, Fakultas Matematika dan Ilmu Pengetahuan Alam Universitas Pakuan melakukan kegiatan Pengabdian Masyarakat yang dimulai dengan kegiatan untuk meningkatkan keterampilan ibu rumah tangga di Desa Cibadak untuk menghasilkan industri rumah tangga melalui pelatihan dan pelatihan pendampingan dalam pembuatan Virgin Coconut Oil (VCO). Melalui kegiatan ini, diharapkan ibu rumah tangga tidak hanya memiliki keahlian untuk membuat produk kreatif dari industri rumah tangga tetapi dapat memasarkannya sehingga di masa depan mereka dapat membantu kesejahteraan ekonomi keluarga. Kegiatan telah dilakukan dari tanggal 19 April 2019 hingga 16 Juni 2019. Kegiatan tersebut dihadiri oleh 20 ibu rumah tangga di wilayah Desa Cibadak. Hasil evaluasi dari kegiatan yang telah dilakukan menunjukkan peningkatan keterampilan ibu rumah tangga di Desa Cibadak untuk menghasilkan produksi industri rumah tangga yang diharapkan dapat meningkatkan ekonomi keluarga. Salah satunya adalah peningkatan kemampuan peserta untuk membuat VCO.
\end{abstract}

Keywords: Community Service, Virgin Coconut Oil.

Abstract: Desa Cibadak is a Desa located in Kecamatan Ciampea, Kabupaten Bogor. One of the obstacles in the economic field in Desa Cibadak is in the industrial aspects, especially the home industry. Based on these problems the Faculty of Mathematics and Natural Sciences of Universitas Pakuan carried out Community Service activities which began with activities to improve the skills of housewives in Desa Cibadak to produce home industries through training and mentoring training in making Virgin Coconut Oil (VCO). Through these activities, it is expected that housewives not only have the expertise to make creative products from home industries but can market them so that in the future they can help the family's economic prosperity. Activities have been carried out from the date of April 19, 2019 to June 16, 2019. Activities were attended by 20 housewives in the Desa Cibadak area. The results of the evaluation of the activities that have been carried out indicate an increase in the skills of housewives in Desa Cibadak to produce home industry production which is expected to improve the family economy. One of them is the increase in the ability of participants to make VCO.

Keywords: Community Service, Virgin Coconut Oil. 


\section{PENDAHULUAN}

Desa Cibadak adalah sebuah Desa yang terletak di Kecamatan Ciampea Kabupaten Bogor. salah satu kendala bidang ekonomi di desa Ciabdak adalah pada aspek industri terutana industri rumah tangga. Berdasarkan permasalahn tersebut Fakultas Matematika dan Ilmu Pengetahuan Alam Universitas Pakuan melaksanakan kegiatan Pengabdian Kepada Masyarakat yang diawali dengan kegiatan peningkatan Keterampilan ibu-ibu rumah tangga di Desa Cibadak untuk menghasilkan industri rumah tangga melalui pelatihan dan pendampingan dalam pembuatan Virgin Coconut Oil (VCO). Melalui kegiatan tersebut diharapkan ibu-ibu rumah tangga tidak saja punya keahlian dalam membuat produk-produk kreatif hasil industri rumah tangga tetapi dapat memasarkannya sehingga kedepannya dapat membantu kesejahteran ekonomi keluarga. Kegiatan telah dlaksanakan dari Tanggl 19 April 2019 sampai tanggal 16 Juni 2019. Kegiatan di ikuti oleh 20 Ibu-ibu rumah tangga di wilayah Desa Cibadak. Hasil evaluasi terhadap kegiatan yang telah dilaksanakan menjukuan adanya peningkatan keterampilan ibu-ibu rumah tangga di Desa Cibadak untuk menghasilkan produksi industri rumah tangga yang diharapkan dapat meningkatkan perekonomian keluarga.
Salah satunya terliat dari peningkatan kemampuan peserta dalam memebuat VCO. VCO merupakan jenis minyak yang dihasilkan dari santan kelapa. Proses pembuatan VCO ini sama sekali tidak menggunakan zat kimia organik dan pelarut minyak sehingga dengan proses seperti ini rasa minyak yang dihasilkan lembut dengan bau khas minyak kelapa yang unik. Jika membeku, warna minyak kelapa ini putih murni, sedangkan jika mencair, VCO tidak berwarna (bening) [2].

Banyaknya khasiat bagi kesehatan telah meningkatkan penggunaan VCO [3]. Harga VCO yang masih relatif mahal dan produksinya yang masih terbatas dapat menjadi kesempatan usaha bagi masyarakat di Desa Cibadak dengan harapan warga lebih sejahtera dengan bertambahnya keterampilan yang dimiliki. Hal ini disebabkan cara pembuatan VCO mudah dilakukan oleh industri rumahan. Meskipun Desa Cibadak tidak memiliki sumber daya alam penghasil kelapa sebagai bahan baku pembuatan VCO, akan tetapi kelapa dapat diperoleh dengan mudah di pasaran dengan harga yang relatif murah, sementara harga jual produk VCO jauh lebih tinggi dibandingkan biaya produksi. Dengan demikian, masyarakat akan memperoleh keuntungan yang menjanjikan. Selain itu kegiatan ini yang pada awalnya untuk keperluan keluarga dan skala kecil, secara 
bertahap dapat dikembangkan menjadi usaha skala rumah tangga (home industry) dimana produk dipasarkan secara lebih luas lagi.

\section{METODE PELAKSANAAN}

Metoda pelaksanaan kegiatan Pengabdian Masyarakat dalam Peningkatan Keterampilan Industri Rumah Tangga Bagi Ibu-ibu Rumah Tangga di Desa Cibadak, Kecamatan Ciampea, Kabupaten Bogor Melalui Pelatihan dan Pendampingan Pembuatan Virgin Coconut Oil (VCO). Tahapan-tahapannya ditunjukan pada Gambar 1

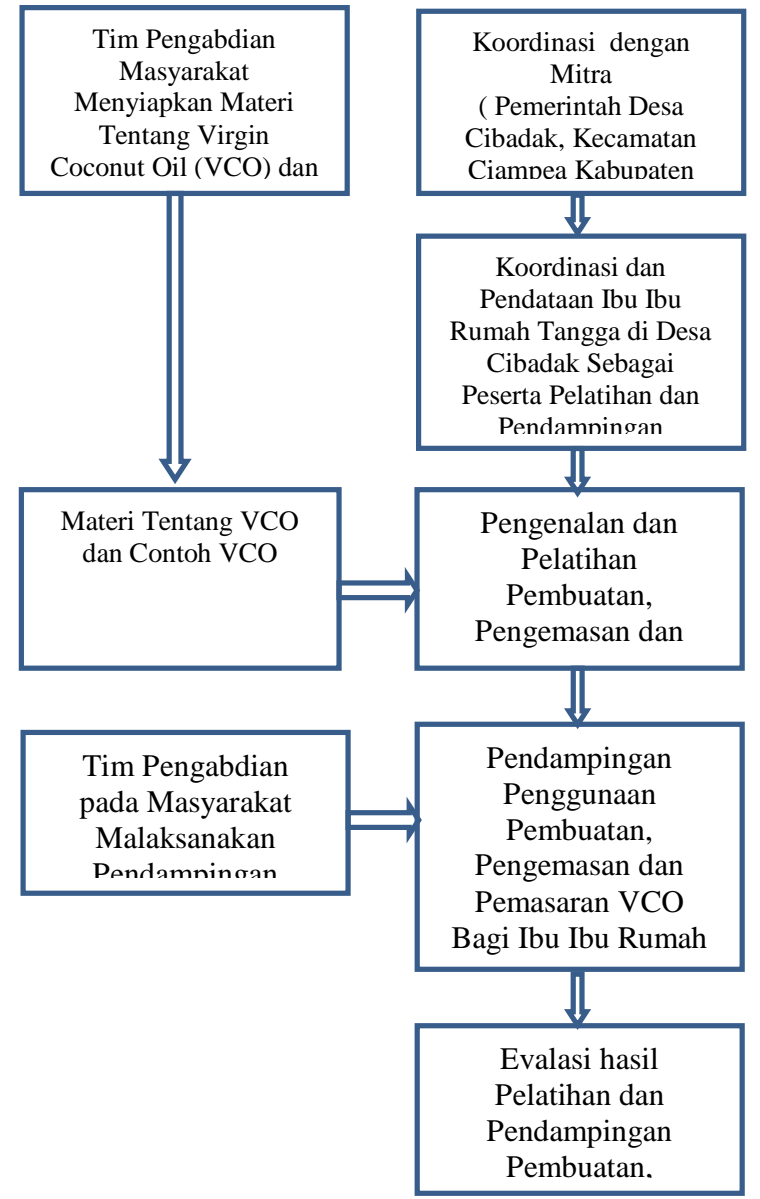

Gambar 1. Metode Pelaksanaan a. Tahap awal kegiatan adalah tim Pengabdian Masyarakat berkoordinasi dengan mitra dalam hal ini Pemerintah Desa Cibadak di Kecamatan Ciampea Kabupaten Bogor serta dengan peserta pelatihan dalam hal ini ibu-ibu rumah tangga di Desa Cibadak

b. Tahap kedua tim Pengabdian Masyarakat menyiapkan Materi tentang pengenalan Virgin Coconut Oil (VCO) dan membuat Contoh VCO

c. Tahap ketiga adalah pengenalan dan pelatihan pembuatan, pengemasan dan pemasaran Virgin Coconut Oil bagi Ibu-Ibu Rumah Tangga di Desa Cibadak

d. Tahap keempat adalah pendampingan pembuatan, pengemasan dan pemasaran Virgin Coconut Oil bagi Ibu-Ibu Rumah Tangga di Desa Cibadak

e. Tahap akhir adalah evaluasi bagi para peserta pelatihan dan pendampingan pembuatan, pengemasan dan pemasaran VCO bagi Ibu-Ibu Rumah Tangga di Desa Cibadak. Adapun tahap evaluasi ini dibagi ke dalam 2 (dua) kategori yakni

- Evaluasi jangka pendek yang dilakukan selama pengenalan dan pelatihan berlangsung.

- Evaluasi jangka panjang yang dilakukan melalui monitoring terhadap implementasi pembuatan VCO. 
Evaluasi dilakukan dengan cara kunjungan selama pendampingan Kegiatan ini merupakan tahap evaluasi jangka panjang yang sekaligus sebagai media tionsultasi bagi para peserta pelatihan dengan tim pengabdian masyarakat untuk membantu penyelesaian kendala-kendala nyata yang dihadapi dan sekaligus menjadi media evaluasi akhir sebagai indikator keberhasilan pelaksanaan kegiatan pengabdian masyarakat

\section{HASIL DAN PEMBAHASAN}

A. Koordinasi ke mitra yaitu Pemerintahan Desa Cibadak Kecamatan Ciampea kabupaten Bogor

Program Pengabdian pada Masyarakat diawali dengan kunjungan ke Desa Cibadak di Kecamatan Ciampea Kabupaten Bogor yaitu pada tanggal 1 April 2019. Adapun tujuan dari kunjungan adalah

1. Perkenalan Tim Pengabdian Masyarakat dengan Mitra yaitu Pemerintahan Desa Cibadak dan Ibuibu rumah tangga di Desa Cibadak sebagai calon peserta Pelatihan pembuatan VCO

2. Menyampaikan tujuan dan rencana Program Kegiatan Pengabdian Masyarakat yang akan dilaksanakan
Adapun dokumentasi kunjungan ke mitra di Desa Cibadak ditunjukan pada Pada Gambar 2.

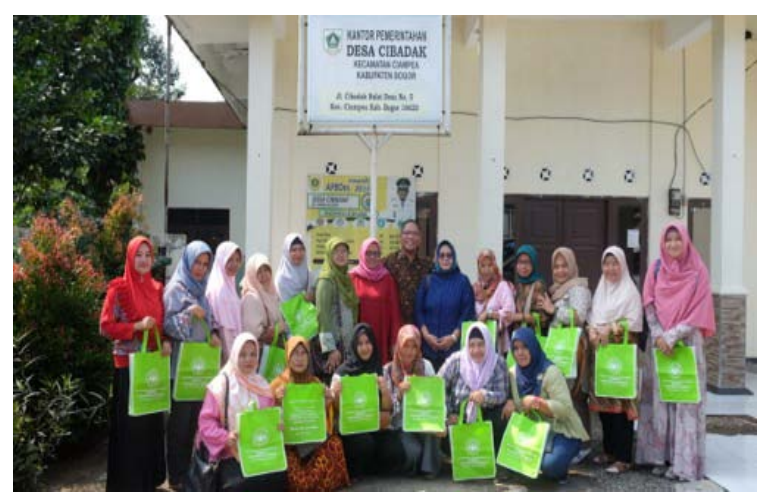

Gambar 2 Kunjungan Ke Mitra di Desa Cibadak

B. Menyiapkan Materi Pengenalan Virgin Coconut Oil (VCO) dan Membuat Contoh VCO

Sebagai persiapan dalam kegiatan pelatihan pembuatan, pengemasan dan pemasaran VCO bagi ibu-ibu rumah tangga di Desa Cibadak. Tim pengabdian masyarakat menyiapkan materi tentang pengenalan VCO. Pada materi ini disampaikan antara lain tentang apa VCO, apa saja zat yang terkandung dalam VCO, apa manfaat VCO serta bagimana tahapantahapan pembuatan dan pengemasan VCO. Selain itu disampaikan pula bagaimana strategi promosi dan pemasaran VCO melalui media sosial.

Dalam mempermudah penyampikan Materi tentang VCO, Tim telah membuat terlebih dahulu VCO, Sehingga dapat 
dijadikan contoh yang akan diperlihatkan kepada peserta pelatihan.

\section{Mengadakan Pelatihan Pembuatan,} pengemasan dan pemasaran VCO

Pelatihan pembuatan, pengemasan dan pemasaran VCO sebagai kegiatan awal diikuti oleh 20 peserta yang terdiri dari ibuibu rumah tangga perwakilan dari beberapa RW yang ada di Desa Cibadak. Pelatihan dilaksanakan di Aula Desa Cibadak Kecamatan Ciampea Kabupaten Bogor. Sebelum diberi pelatihan dilaksankan terlebih dahulu dilaksanakan pembukaan kegiatan Pengabdian Masyarakat oleh Ketua PKK Desa Cibadak yang dilanjutkan dengan pemberian materi pengenalan VCO, cara pembuatan dan pengemasan serta pemasarannya. Adapun kegiatan pembukaan dan pemberian materi Pengenalan VCO dilaksanakan pada tanggal 19 April 2019 seperti ditunjukan pada Gambar 3. Kegiatan praktikum pembuatan VCO dilaksanakan pada tanggal 26 April 2019 seperti di tunjukan pada Gambar 4. Sedangkan panen dan cara pengemasan VCO dilaksankan pada tanggal 15 dan 16 Juni 2019. Seperti di tunjukan pada Gambar 5 dan Gambar 6.

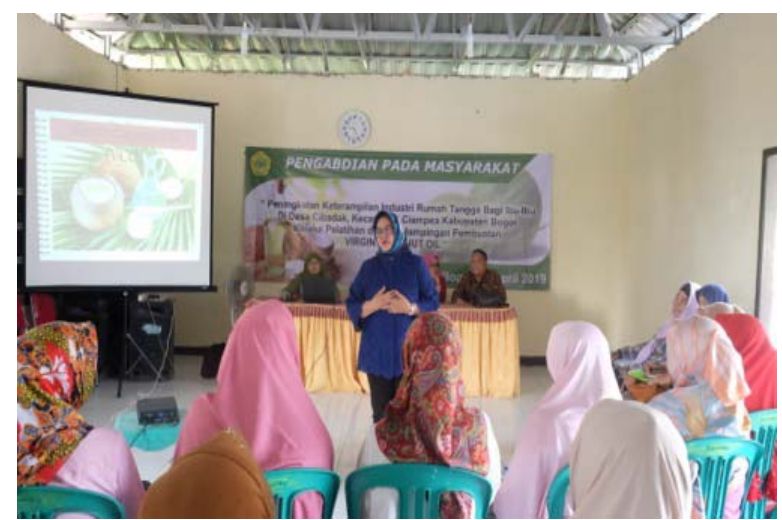

Gambar 3. Pembukaan dan Pemberian Materi Pengenalan VCO

Adapun tahapan-tahapan pembuatan VCO adalah sebagai berikut :

- Siapkan kelapa yang sudah diparut yang diperoleh dari 5 buah kelapa yang dibersihkan kulitnya.

- Kelapa dimasukkkan ke dalam wadah, selanjutnya ditambahkan $1,5 \quad 1$ air hangat, selanjutnya diaduk sampai rata

- Kelapa dimasukkan ke dalam kain batis dan diperas sampai semua santan kelapa dapat dikeluarkan

- Santan yang sudah diperoleh diletakkan dalam gelas kaca, selanjutnya dibiarkan selama 2 jam. Setelah 2 jam akan terbentuk 2 lapisan yaitu lapisan kanil di atas dan air terpisah di bagian bawah.

- Kanil yang terbentuk dipisahkan dari air dengan membuang air melalui kran sampai batas kanil.

- Kanil yang terbentuk didiamkan selama 24 jam pada suhu ruang 
- Setelah 24 jam akan terbentuk 3 lapisan, lapisan paling atas merupakan minyak VCO, lapisan kedua merupakan blondo dan lapisan paling bawah adalah air.

- VCO dipanen dengan cara mengaambil secara pelan-pelan bagian VCO dan disaring dengan kertas saring.

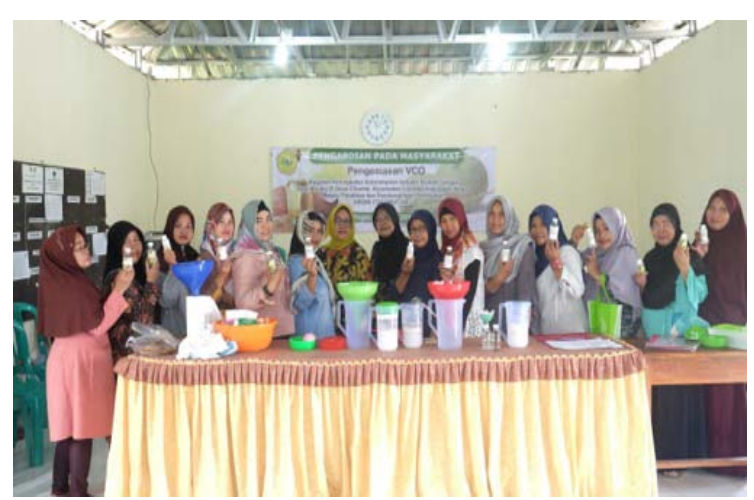

Gambar 5. Praktek Panen dan Pengemasan VCO

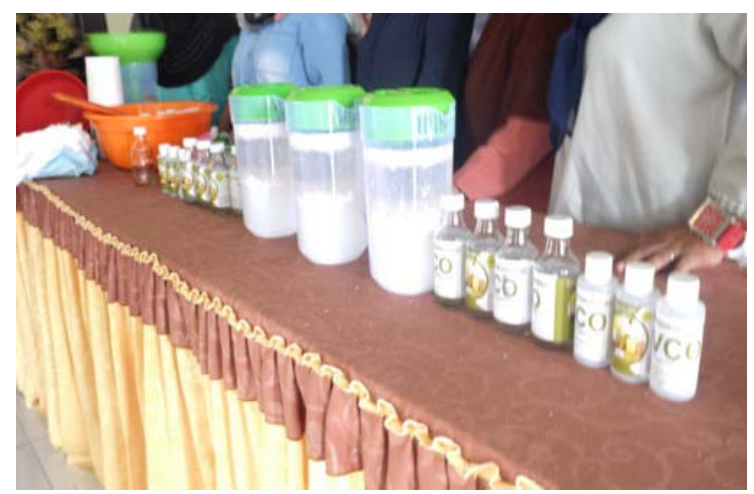

Gambar 5. Hasil Pengemasan VCO

D. Mengadakan

Pendampingan

Pembuatan, Pengemasan dan Pemasaran VCO

Pendampingan dilakukan sebagai evaluasi dan monitoring terhadap implementasi Pembuatan VCO. Evaluasi dilakukan secara periodik kunjungan. Kegiatan ini merupakan tahap evaluasi sekaligus sebagai media konsultasi bagi para peserta pelatihan dengan Tim Pengabdian masyarakat untuk membantu penyelesaian kendala-kendala nyata yang dihadapi dan sekaligus menjadi media evaluasi akhir sebagai indikator 
keberhasilan pelaksanaan kegiatan

Pengabdian Masyarakat dalam

\section{E. Hasil Evaluasi Kegitaan Pelatihan} Pembuatan, pengemasan dan Pemsaaran VCO

Berdasarkan Hasil evaluasi pelaksanaan pelatihan dan pendampingan dalam pembuatan VCO bagi Ibu-ibu rumah tangga di Desa Cibadak. Hasil Kuisioner menujukan adanya peningkatan keterampilan dalam pembuatan dan pengemasan VCO. Akan tetapi masih ada beberapa pesserta yang belum berhasil dalam memproduksi VCO. diduga hal ini terjadi karena beberapa kendala diantara:

- Lokasi pembuatan dan penyimpanan VCO tidak memenuhi syarat. Lokasi pembuatan dan penyimpanan VCO berpengaruh pada hasil dan kualitas VCO, tempat yang lembab dapat menghambat terbentuknya VCO.

- Penggunaan wadah dan tempat yang kurang bersih untuk produksi VCO. Tempat dan wadah yang kurang bersih dapat menghambat terbentuknya minyak VCO.

- Adanya tahapan yang terlewati misalnya penggunaan air dingin untuk pembuatan santan padahal seharusnya digunakan air hangat, usia kelapa yang digunakan dimana kelapa yang bagus untuk pembuatan VCO adalah kelapa yang tua.

Oleh karena itu untuk menangani kendala dan masalah ini telah diadakan pendampingan terus serta diterangkan mengenai kendala yang mungkin muncul saat produksi VCO dan cara menanganinya. Diharapkan setelah pelatihan ini semua kendala dapat diatasi sampai para mitra dapat menghasilkan VCO sendiri.

\section{KESIMPULAN}

Setelah Program Pengabdian pada Masyarakat dilaksanakan yaitu dapat disimpulkan bahwa :

1. Pelatihan industri rumah tangga dalam bagi ibu-ibu rumah tangga di Desa Cibadak, Kecamatan Ciampea, Kabupaten Bogor salah satunya pelatihan dan pendampingan pembuatan Virgin Coconut Oil (VCO) sangat dibutuhkan dan bermanfaat dalam meingkatan keterampilan untuk menghasilkan produksi industri rumah tangga yang diharapkan dapat meningkatkan perekonomian keluarga. Hal ini terliat dari peningkatan kemampuan peserta dalam mmebuat VCO. 
2. Peserta yang bisa mengikuti dan DAFTAR PUSTAKA dapat membuat VCO secara mandiri sebanyak 80 persen. Sedangkan yang memahami strategi pemasaran hanya 30 persen. .Oleh karena itu masih diperlukan pendampingan lebih lanjut sehingga kegiatan ini semakin meniktaN keberhasilannya

\section{UCAPAN TERIMA KASIH}

Terselenggaranya

Kegiatan

Pengabdian Masyarakat dalam Peningkatan Keterampilan Industri Rumah Tangga Bagi Ibu-ibu Rumah Tangga di Desa Cibadak, Kecamatan Ciampea, Kabupaten Bogor Melalui Pelatihan dan Pendampingan Pembuatan Virgin Coconut Oil (VCO). Salah satunya karena dukungan dari beberapa pihak. Oleh karena itu pada kesempatan ini, Tim Pengadian Masyarakat mengucapkan terima kasih kepada :

1. Fakultas Matematika dan Ilmu Pengetahuan Alam Univeritas Pakuan yang telah memberikan bantuan dana dan sarana lainnya sehingga kegiatan bisa berjalan dengan lancar.

2. Pemerintah Desa Cibadak sebagai mitra yang telah mefasilitasi tempat dan mengkoodinir peserta pelatihan

[1] Profil Desa Cibadak, Kecamatan Ciampea Kabupaten Bogor 2019.

[2] Chiaw Mei Sia, Hip Seng Yim, Choon Mei Lai. Commercial virgin coconut oil: assesmnet of antimicrobial potential. As. J. Food Ag-Ind. 3(06) 567-579 2010.

[3] Bogadenta, A. 2013. Manfaat Air Kelapa dan Minyak Kelapa. FlashBooks. Yogyakarta 2013

[4] I Elsje, T. Tenda, M.A. Tulalo and H. Novarianto.. Diversity of Oil and Medium fatty Acid Content Of local Coconut Cultivars Grown on Different Altitudes. Indonesian Journal of Agriculture. 2009

[5] Syafira, E. VCO fakta dari Laboratorium. Majalah Trubus, No 430 hal. 11-15].2005

[6] Setiadji,B. dalam S. Winarti dkk. 2004. Memancing minyak kelapa dengan Minyak Kelapa. Tempo, 18 Juli 2004 